\title{
Karyotypic description of the stingless bee Oxytrigona cf. flaveola (Hymenoptera, Apidae, Meliponina) of a colony from Tangará da Serra, Mato Grosso State, Brazil
}

\author{
Diones Krinski ${ }^{1}$, Anderson Fernandes ${ }^{1}$, Marla Piumbini Rocha ${ }^{2}$ and Silvia das Graças Pompolo ${ }^{3}$ \\ ${ }^{l}$ Departamento de Ciências Biológicas, Universidade do Estado de Mato Grosso, Tangará da Serra, \\ MT, Brazil. \\ ${ }^{2}$ Departamento de Morfologia, Universidade Federal de Pelotas, Pelotas, RS, Brazil. \\ ${ }^{3}$ Departamento de Biologia Geral, Universidade Federal de Viçosa, Viçosa, MG, Brazil.
}

\begin{abstract}
The aim was to broaden knowledge on the cytogenetics of the subtribe Meliponina, by furnishing cytogenetic data as a contribution to the characterization of bees from the genus Oxytrigona. Individuals of the species Oxytrigona cf. flaveola, members of a colony from Tangará da Serra, Mato Grosso State, Brazil, were studied. The chromosome number was $2 n=34$, distributed among four chromosomal morphologies, with the karyotype formula $8 m+8 s m+16 s t+2 t$. Size heteromorphism in the first metacentric pair, subsequently confirmed by sequential staining with fluorochrome (DA/DAPI/CMA $)$, was apparent in all the examined individuals The nucleolar organizing regions (NORs) are possibly located in this metacentric chromosome pair. These data will contribute towards a better understanding of the genus Oxytrigona. Given that species in this group are threatened, the importance of their preservation and conservation can be shown in a sensible, concise fashion through studies such as this.
\end{abstract}

Key words: chromosome, heteromorphism, fluorochrome.

Received: December 14, 2009; Accepted: March 30, 2010.

The number of stingless bee species (subtribe Meliponina) found in the Neotropics is extremely high, with approximately 400 known to date (Biesmeijer and Slaa, 2004). In Brazil, there are 192 already described species, belonging to 27 genera (Silveira et al., 2002). Studies have reached the cytogenetic level in 75 , whereas in many only the chromosome number has been determined (Rocha et al., 2003). Thus, the urgent need for further studies, as many native species of social bees are becoming extinct, through the destruction of their habitats by deforestation, forest fires, the lumber industry, insecticides and honey collectors (Kerr et al., 2001).

Certain groups of meliponines, such as the genus Oxytrigona, have specific characteristics. Bees of this genus are commonly known as "cospe-fogo" (fire spitting), due to the peculiar characteristic of secreting a caustic liquid (formic acid) from the mandibular glands, thereby giving rise to severe burns in both animals and humans, while leaving permanent spots on the skin. Besides being highly aggressive, they are also cleptobiotic, as colony robbers of

Send correspondence to Diones Krinski. Departamento de Ciências Biológicas, Universidade do Estado de Mato Grosso, Rodovia MT 358, km 07, Jardim Aeroporto, 78300-000 Tangará da Serra, MT, Brazil. E-mail: dioneskrinski@ibest.com.br. other meliponine species (Roubik et al., 1987; Roubik, 1992; Souza et al., 2007).

The genus was last reviewed by Schwarz (1948), who only recognized one species, Oxytrigona tataira, yet it is now considered to include several subspecies and even undescribed species (Silveira et al., 2002). Michener (2000) reported the existence of eight species of Oxytrigona in the Neotropics, six of which were found in Colombia (NatesParra, 2001), during a study on local stingless bees. Recently, Gonzalez and Roubik (2008) reviewed the genus and described 11 species of Oxytrigona.

Among those species of Oxytrigona so far studied cytogenetically, only the chromosome umber of $O$. tataira $(\mathrm{n}=17)$ was placed in evidence by the crushing technique, thereby revealing four morphological types of chromosomes, classified in decreasing order based on size (Kerr, 1972).

In the state of Mato Grosso (Brazil), the cytogenetic study of bees as a whole, is rare (Costa et al., 2004). Therefore, there is a need for a cytogenetic study on Oxytrigona cf. flaveola, which is found in this region, especially considering the current threat of extinction to approximately 100 bee species, as emphasized by Kerr et al. (1996).

Further studies of these bees would contribute towards the characterization and correct classification of spe- 
cies. Cytogenetic analysis is a resource that, together with other areas of research, has offered contributions to knowledge on phylogeny (Costa et al., 2003; Camargo and Pedro, 2003; Rocha et al., 2003; Rasmussen and Cameron, 2007; Gonzalez and Roubik 2008), speciation mechanisms (Tavares et al., 2007; Lopes et al., 2008; Souza et al., 2008) and genetic variability (Rocha et al., 2002; Domingues et al., 2005; Martins et al., 2009), seeing that chromosomes are the physical basis of the genetic system.

A colony of $O$. cf. flaveola was collected from a wall in the urban area of Tangará da Serra (14³7'42" S, 57²9'53” W), Mato Grosso State, Brazil, to be used for cytogenetic analysis. Voucher specimens are deposited in the Biology Laboratory of the Universidade do Estado de Mato Grosso, Tangará da Serra campus. The material used to obtain metaphase chromosomes was extracted from the cerebral ganglia of 20 post-defecating $O$. cf. flaveola larvae, according to the methodology developed by Imai et al. (1988). A minimum of 10 metaphases per specimen were analyzed.

Conventional staining was carried out with a solution of $1 \mathrm{~mL}$ of Giemsa, in $30 \mathrm{~mL}$ of Sörensen buffer $0.06 \mathrm{M}$ $(\mathrm{pH}=6.8)$ for $25 \mathrm{~min}$ at room temperature, followed by sequential staining with fluorochromes (4'-6-diamidino-2phenylindole - DAPI and chromomycin $\mathrm{A}_{3}-\mathrm{CMA}_{3}$ ) (Schweizer, 1980). 4'-6-diamidino-2-phenylindole (DAPI) is a fluorochrome that binds to AT and GC bases. Nevertheless fluorescence intensity is significantly higher with DNA rich in AT bases, thereby generating more pronounced, brilliant regional banded patterns. Chromomycin $\mathrm{A}_{3}\left(\mathrm{CMA}_{3}\right)$ is an antibiotic with affinity for $\mathrm{GC}$ base pairs (Sumner, 1990). Furthermore, $\mathrm{CMA}_{3}$ regions are generally associated with nucleolar organizer regions (NORs).

Metaphase cells revealed by Giemsa and fluorochrome staining were captured by a CCD camera (OPTRONICS, model DEI-470) connected to an Olympus TM BX60 microscope equipped with epifluorescence, with a WB filter $(\lambda=450-480 \mathrm{~nm})$ and immersion objectives at 100x magnification. Graphs and karyograms were constructed using an image analysis program (Image-Pro ${ }^{\circledR}$ Plus, version 3.1, Media Cybernetics, 1998).

Oxytrigona cf. flaveola proved to have $2 \mathrm{n}=34$ chromosomes (Figure 1a), as previously observed in $O$. tataira (Kerr, 1972). The four morphological chromosome types were determined based on nomenclature as proposed by Levan et al. (1964): four metacentric pairs (m), four submetacentric pairs (sm), eight subtelocentric pairs (st) and one telocentric pair $(\mathrm{t})$ for diploid individuals, thereby furnishing the karyotype formula $8 m+8 s m+16 s t+2 t$ (Figure 1a). Size heteromorphism was found in the first chromosome pair of all the individuals analyzed (Figure 1a, b). Oxytrigona cf. flaveola has a higher chromosome number than previously karyotyped species belonging to the tribe Meliponini (Pompolo, 1992; Rocha and Pompolo, 1998; Rocha et al., 2002, 2003), with most chromosomes being either submetacentric or subtelocentric. Studies on 27 genera of the tribe gave note of haploid chromosome numbers ranging from 8 to 20 chromosomes (Kerr, 1948, 1952, 1969, 1972; Kerr and Silveira, 1972; Hoshiba, 1988, Hoshiba and Imai, 1993; Pompolo, 1994; Brito-Ribon et al., 1999).

The high chromosome number of $O$. cf. flaveola may be related to centric fission, as proposed by the theory of minimal interaction (Imai et al., 1988). According to this theory, the karyotype evolved as a means of minimizing genetic damage through centric fission, with the consequential increase in chromosome number. The regions of fission would correspond to an unstable telomeric region. Chromosome stability would be regained with in tandem growth of regional heterochromatin, thereby generating heterochromatic arms.

Sequential staining showed that chromosomes of pair 1 are preferably $\mathrm{CMA}_{3}{ }^{+}$. These chromosomes had one arm preferentially stained by $\mathrm{CMA}_{3}$ fluorochromes, usable for revealing size heteromorphism (Figure 1b). Brito et al. (2003) reported $\mathrm{CMA}_{3}{ }^{+}$heteromorphic markings found in the large chromosomes of some species of Partamona, a possible indication of phylogenetic relationship between the genera Partamona and Oxytrigona, as suggested by Costa et al. (2003).

There are two hypotheses for explaining heteromorphism in pair one: (1) the small chromosome could be an ancestral condition, with the larger originating through in tandem amplification of regions rich in $\mathrm{GC}$ pairs $\left(\mathrm{CMA}_{3}{ }^{+}\right)$; and (2) the large chromosome would be the ancestral condition, with the smaller originating from deletion of a portion of the former. Thus, cytogenetic analysis of other $O$. cf. flaveola colonies might provide relevant data to prove either of the two hypotheses.

GC bases were prevalent in the region marked by $\mathrm{CMA}_{3}$ in pair 1 of $O$. cf. flaveola, thereby implying that this chromosome may contain sites of ribosomal DNA sequences, since there is generally an association between the presence of nucleolar organizer regions (NORs) with $\mathrm{CMA}_{3}$ labeling in the same chromosome region (Sumner, 1990).

A positive correlation between $\mathrm{CMA}_{3}$ and NORs has been reported in several species of the subtribe Meliponina, as Partamona mulata and Partamona vicina (Brito-Ribon et al., 1999), Partamona peckolti (Brito et al., 2003), Partamona helleri and Partamona seridoensis (Brito et al., 2005), Trigona fulviventris (Domingues et al., 2005), and four other species of Trigona (Costa et al., 2004).

The scarcity of biological information on bees from the subtribe Meliponina, especially the genus Oxytrigona, underlines the importance of further cytogenetic knowledge of this group, as a whole. This could be useful in orientating taxonomy and conservation methods. Cytogenetics directly affects progress in taxonomy studies, by ensuring biological data with the elimination of subjectivity in sys- 
a

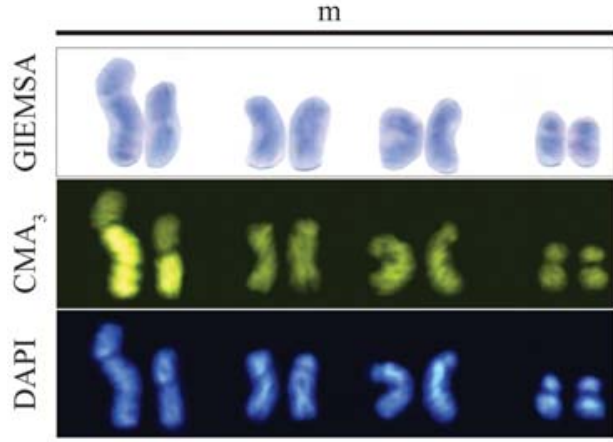

01
02
03
04

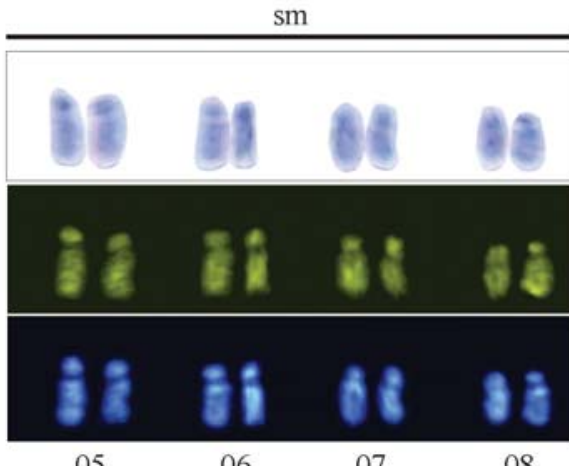

05

06

07

08
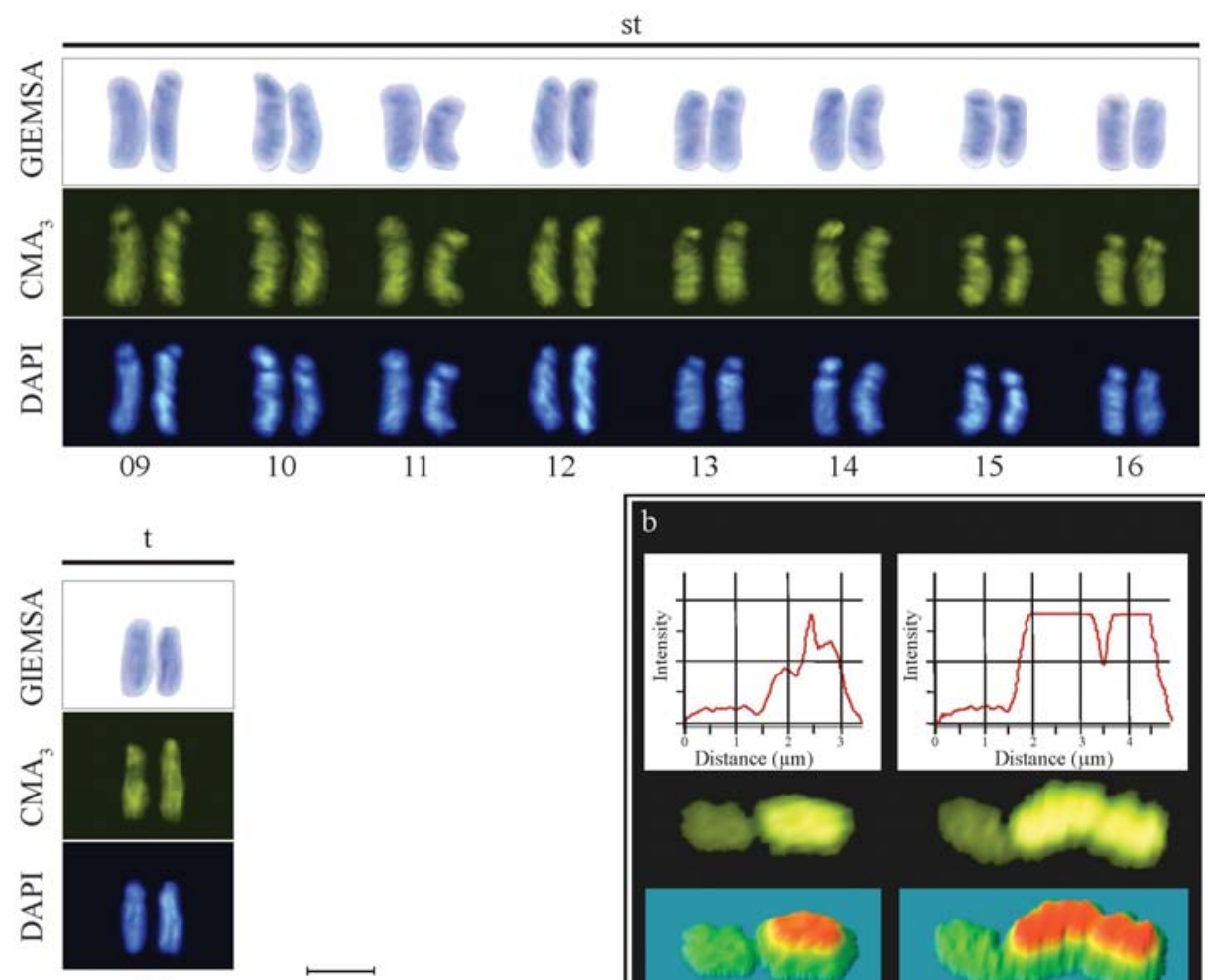

17

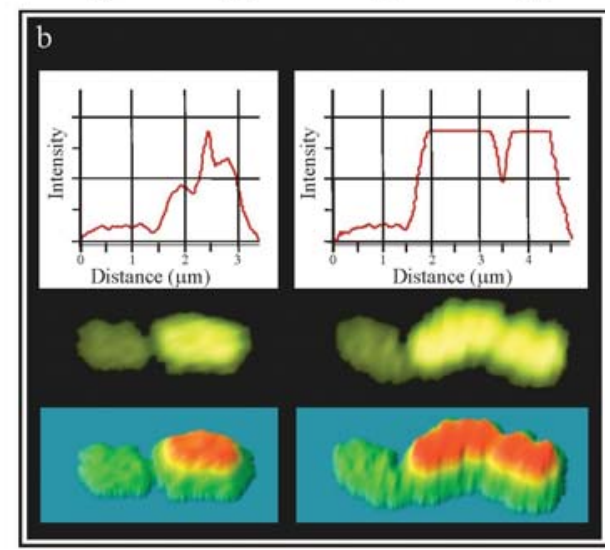

Figure 1 - Mitotic chromosomes of Oxytrigona cf. flaveola sequentially stained with (a) Giemsa, CMA 3 and DAPI. The karyotype presented four metacentric pairs, four submetacentric, eight subtelocentric and one telocentric for diploid individuals. (b) Heteromorphism of fluorescence intensity and the size of the arm preferentially stained by fluorochrome $\mathrm{CMA}_{3}$ in the first chromosome pair. Scale bar: $5 \mu \mathrm{m}$.

tematic classification, especially in the Meliponina, through numerical taxonomy (Kerr et al., 1967).

The information obtained in this work, besides being of use in future cytotaxonomic studies, will be of assistance in comparative analyses, as a means of clarifying both taxonomic problems and those phenomena involved in karyotype evolution in this group.

\section{Acknowledgments}

The authors wish to thank the Fundação de Amparo à Pesquisa do Estado de Mato Grosso (FAPEMAT), Conselho Nacional de Desenvolvimento Científico e Tecno- lógico (CNPq), Coordenação de Aperfeiçoamento de Pessoal de Nível Superior (CAPES) and Universidade do Estado de Mato Grosso (UNEMAT) for financial support, as well as the members of the Animal Biology Laboratory of UNEMAT, who accompanied and helped during this study, and Dr. Favízia Freitas de Oliveira (UEFS, Feira de Santana, BA) for taxonomic identification of Oxytrigona cf. flaveola.

\section{References}

Biesmeijer JC and Slaa EJ (2004) Information flow and organization of stingless bee foraging. Apidologie 35:143-157. 
Brito-Ribon RM, Miyazawa CS and Pompolo SG (1999) First karyotype characterization of four species of Partamona (Friese, 1980) (Hymenoptera, Apidae, Meliponinae) in Mato Grosso State, Brazil. Cytobios 100:19-26.

Brito RM, Caixeiro AP, Pompolo SG and Azevedo GG (2003) Cytogenetic data of Partamona pecktolti (Hymenoptera, Apidae, Meliponini) by $\mathrm{C}$ banding and fluorochrome staining with $\mathrm{DA} / \mathrm{CMA}_{3}$ and DA/DAPI. Genet Mol Biol 26:5357.

Brito RM, Pompolo SG, Magalhães MFM, Barros EG and Sakamoto-Hojo ET (2005) Cytogenetic characterization of two Partamona species (Hymenoptera, Apinae, Meliponini) by fluorochrome staining and localization of $18 \mathrm{~S}$ rDNA clusters by FISH. Cytologia 70:373-380.

Camargo JMF and Pedro SEM (2003) Sobre as relações filogenéticas de Trichotrigona Camargo \& Moure (Hymenoptera, Apidae, Meliponini). In: Melo GAR and Alves-dos-Santos I (eds) Apoidea Neotropica: Homenagem aos 90 Anos de Jesus Santiago Moure. Editora UNESC, Criciúma, pp 109122.

Costa KF, Brito RM and Miyazawa CS (2004) Karyotypic description of four species of Trigona (Jurine, 1807) (Hymenoptera, Apidae, Meliponini) from the State of Mato Grosso, Brazil. Genet Mol Biol 27:187-190.

Costa MA, Del Lama MA, Melo GAR and Sheppard WS (2003) Molecular phylogeny of the stingless bees (Apidae, Apinae, Meliponini) inferred from mitochondrial 16S rDNA sequences. Apidologie 34:73-84.

Domingues AMT, Waldschmidt AM, Andrade SE, Andrade-Souza V, Alves RMO, Silva JJC and Costa MA (2005) Karyotype characterization of Trigona fulviventris Guérin, 1835 (Hymenoptera, Meliponini) by C banding and fluorochrome staining: Report of a new chromosome number in the genus. Genet Mol Biol 28:390-393.

Gonzalez VH and Roubik DW (2008) Especies nuevas y filogenia de las abejas de fuego, Oxytrigona (Hymenoptera, Apidae, Meliponini). Acta Zool Mex 24:43-71 (Abstract in English).

Hoshiba H (1988) Karyological analysis of a stingless bee Melipona favosa (Apidae, Hymenoptera). Cytologia 53:153156.

Hoshiba H and Imai HT (1993) Chromosome evolution of bees and wasps (Hymenoptera, Apocrita) on the basis of C-banding pattern analyses. Jpn J Entomol 61:465-492.

Imai HT, Taylor RW, Crosland MWJ and Crozier RH (1988) Modes of spontaneous chromosomal mutation and karyotype evolution in ants with reference to the minimum interaction hypothesis. Jpn J Genet 32:159-185.

Kerr WE (1948) Estudos sobre o gênero Melipona. Ann Esc Agr "Luiz de Queiroz"' 5:182-276.

Kerr WE (1952) A variação do número de cromosomas na evolução dos Hymenoptera. Sci Genet 4:182-190.

Kerr WE (1969) Some aspects of the evolution of the social bees. Evol Biol 3:119-175.

Kerr WE (1972) Numbers of chromosomes in some species of bees. J Kans Entomol Soc 45:111-122.

Kerr WE and Silveira ZV (1972) Karyotypic evolution of bees and corresponding taxonomic implications. Evolution 26:197-202.

Kerr WE, Carvalho GA and Nascimento VM (1996) Abelha Uruçu. Biologia, Manejo e Conservação. Coleção Manejo da Vida Silvestre, v. 2. Fundação Acangaú, Belo Horizonte, $143 \mathrm{pp}$.

Kerr WE, Pisani JF and Aily D (1967) Aplicação de princípios modernos à sistemática do gênero Melipona Illiger, com a divisão em dois subgêneros (Hymenoptera, Apoidea). Papéis Avulsos Zool 20:135-145.

Kerr WE, Carvalho AG, Silva AC and Assis MGP (2001) Aspectos poucos mencionados da biodiversidade amazônica. Biodiversidade, pesquisa e desenvolvimento da Amazônia. Parcerias Estrat 12:21-41 (Abstract in English).

Levan A, Fredga K and Sandberg AA (1964) Nomenclature for centromeric position on chromosomes. Hereditas 52:201220.

Lopes DM, Pompolo SG, Campos LAC and Tavares MG (2008) Cytogenetic characterization of Melipona rufiventris Lepeletier 1836 and Melipona mondury Smith 1863 (Hymenoptera, Apidae) by $\mathrm{C}$ banding and fluorochromes staining. Genet Mol Biol 31:49-52.

Martins CCC, Duarte OMP, Waldschmidt AM, Alves RMO and Costa MA (2009) New occurrence of B chromosomes in Partamona helleri (Friese, 1900) (Hymenoptera, Meliponini). Genet Mol Biol 32:782-785.

Michener CD (2000) The Bees of the World. Johns Hopkins University Press, Baltimore, 913 pp.

Nates-Parra G (2001) Las abejas sin aguijón (Hymenoptera, Apidae, Meliponini) de Colombia. Biota Colomb 2:233-248 (Abstract in English).

Pompolo SG (1992) Estudos citogenéticos em meliponinae. Naturalia (Special Issue):62-66.

Pompolo SG (1994) Análise dos cariótipos de 19 gêneros de abelhas da subfamília Meliponinae. Anais do $1^{\circ}$ Encontro sobre Abelhas. Ribeirão Preto, pp 143-146.

Rasmussen C and Cameron SA (2007) A molecular phylogeny of the Old World stingless bees (Hymenoptera, Apidae, Meliponini) and the non-monophyly of the large genus Trigona. Syst Entomol 32:26-39.

Rocha MP and Pompolo SG (1998) Karyotypes and heterochromatin variation (C-bands) in Melipona species (Hymenoptera, Apidae, Meliponinae). Genet Mol Biol 21:41-45.

Rocha MP, Pompolo SG, Dergan JA, Fernandes A and Campos LAO (2002) DNA characterization and karyotypic evolution in bees genus Melipona (Hymenoptera, Meliponini). Hereditas 136:19-27.

Rocha MP, Pompolo SG and Campos LAO (2003) Citogenética da tribo Meliponini (Hymenoptera, Apidae). In: Melo GAR and Alves dos Santos I (eds) Apoidea Neotropica: Homenagem aos 90 Anos de Jesus Santiago Moure. UNESC, Criciúma, pp 311-320.

Roubik DW, Smith BH and Carlson RL (1987) Formic acid in caustic cephalic secretions of stingless bee Oxytrigona (Hymenoptera, Apidae). J Chem Ecol 13:1079-1086.

Roubik DW (1992) Stingless bees: A guide to Panamanian and Mesoamerican species and their nests (Hymenoptera, Apidae, Meliponinae). In: Quintero D and Aiello A (eds) Insects of Panamá and Mesoamerica. Oxford University Press, Oxford, pp 495-524.

Schweizer D (1980) Simultaneous fluorescent staining of R bands and specific heterochromatin regions (DA DAPI-bands) in human chromosomes. Cytogenet Cell Genet 75:190-193.

Schwarz HF (1948) Stingless bees (Meliponidae) of the western hemisphere. Lestrimelitta and the following subgenera of 
Trigona: Trigona, Paratrigona, Schwarziana, Parapartamona, Cephalotrigona, Oxytrigona, Scaura, and Mourella. Bull Am Mus Nat Hist 90:1-546.

Silveira FA, Melo GAR and Almeida EAB (2002) Abelhas Brasileiras - Sistemática e Iidentificação. IDM Composição e Arte, Belo Horizonte, 253 pp.

Souza BA, Alves RMO and Carvalho CAL (2007) Diagnóstico da arquitetura de ninho de Oxytrigona tataira (Smith, 1863) (Hymenoptera, Meliponinae). Biota Neotrop 7:83-86 (Abstract in English).

Souza RO, Moretto G, Arias MC and Del Lama MA (2008) Differentiation of Melipona quadrifasciata L. (Hymenoptera, Apidae, Meliponini) subspecies using cytochrome b PCRRFLP patterns. Genet Mol Biol 31:445-450.
Sumner AT (1990) Chromosome Banding. Unwin Hyman Ltd, London, $434 \mathrm{pp}$.

Tavares MG, Dias LAS, Borges AA, Lopes DM, Busse AHP, Costa RG, Salomão TMF and Campos LAO (2007) Genetic divergence between populations of the stingless bee uruçu amarela (Melipona rufiventris group, Hymenoptera, Meliponini): Is there a new Melipona species in the Brazilian state of Minas Gerais? Genet Mol Biol 30:667-675.

Associate Editor: Yatiyo Yonenaga-Yassuda

License information: This is an open-access article distributed under the terms of the Creative Commons Attribution License, which permits unrestricted use, distribution, and reproduction in any medium, provided the original work is properly cited. 